https://helda.helsinki.fi

\title{
Crime and Punishment
}

\section{Nuotio, Kimmo Teppo}

Springer

2019

Nuotio , K T \& Lappi-Seppälä , S T 2019 , Crime and Punishment . in Nordic Law in

European Context . Ius Gentium: Comparative Perspectives on Law and Justice, no. 73 ,

Springer , Cham , pp. 179-199 . https://doi.org/10.1007/978-3-030-03006-3_11

http://hdl.handle.net/10138/309196

https://doi.org/10.1007/978-3-030-03006-3_11

unspecified

acceptedVersion

Downloaded from Helda, University of Helsinki institutional repository.

This is an electronic reprint of the original article.

This reprint may differ from the original in pagination and typographic detail.

Please cite the original version. 


\section{Crime and Punishment}

\section{Tapio Lappi-Seppälä and Kimmo Nuotio}

Lappi-Seppälä: University of Helsinki, Institute of Criminology and Legal Policy, Helsinki, Finland, tapio.lappi-seppala@helsinki.fi

Nuotio, Professor: University of Helsinki, Faculty of Law, Helsinki, Finland, kimmo.nuotio@helsinki.fi

Nordic criminal justice systems are based on shared histories and traditions, common model of society (Nordic Welfare State), as well as over 50-year cooperation in legal issues. For some periods, Finland, however, has followed its own paths, as result of severe political crises in first part of the 20th century. This period was followed by a profound revisions of criminal law and a dramatic decrease in the use of imprisonment in 1960 to 1990 s from over 150 to 60 prisoners / 100000 population. These experiences are worthwhile to study when most countries are still experiencing increasing incarceration rates. And so are the underlying principles of Nordic penal policy, which still rest on the values of Nordic Welfare State and the idea that social policy is the best criminal policy.

\section{Introduction}

\subsection{Early History}

From 1200 to 1400 criminal sanctions in the early Nordic lands consisted mainly of monetary penalties. Imprisonment as a general punishment was unknown; corporal punishment was rare; and death sentences were reserved for very few offences. During the period 1500-1600, centralized power became more established and criminal justice gradually became more severe. However, it never reached the level of brutality observable in continental Europe or in England, a point noted by Nordic legal scholars in the late 1800 s.

Explanations for this "early Nordic exceptionalism" range from cultural factors, to social and demographic factors (in comparison to continental Europe, the Nordic countries did not suffer from the mass poverty which

\footnotetext{
${ }^{1}$ Olivecrona SRDK (1891), Forsman J (1896).
} 
contributed to widespread unrest and rebellion to be met with increased penal repression), a combination of geographical factors and penal ideology (the deterrent effect of public executions was deemed to be much more modest in sparsely populated Nordic countries compared to a densely populated European metropolis) and to structural and political arguments. The Nordic countries never adopted full-scale feudal structures, and landowners were never granted judicial powers which would have enabled implementation of criminal law for private interests. ${ }^{2}$

\subsection{Modern Criminal Law Reform}

The Nordic codes of the late 1600s and early 1700s cannot be classified as inherently reformist. They were based on old provincial codes and subsequent royal legislation. They were products of the age of absolutism, inspired by Mosaic law, deterrence and the Lex Talionis, untouched by Enlightenment ideas and legal scholarship which were about to spread across Europe during the 1700s. This development reached the North in the 1800 s, at all levels.

In the mid-1800s the Nordic countries carried out comprehensive reforms of their criminal law. Prison played the role of principal punishment for serious offences, replacing corporal punishment. Preparations for a new criminal code started in Sweden in the early 1800s; the first proposal was presented in 1832 and ultimately accepted in 1864. Preparations for a new criminal code in Norway and Denmark started at about the same time. Norway was also the first country to complete the work in the form of a new criminal code in 1842. This first Nordic criminal code was strongly influenced by recent German codes, the texts of Paul Johann Anselm Feuerbach and the French Code Pénal. Danish reform took longer. After two unsuccessful attempts to initiate total criminal law reform, a commission appointed in 1850 managed to finalize the task in 1866 . The code follows the Norwegian code in many details.

Reform in Finland was stalled by state-political reasons. The first preparations for reform of sanctions and criminal law started in the 1820s, though actual law drafting ceased after the separation of Finland from Sweden in 1809. The Estates gathered for the first time under the Russian regime in 1863 and partial reform covering enforcement of sanctions was

\footnotetext{
${ }^{2}$ Lappi-Seppälä T (1982), p 61-62, Pratt J, Eriksson A (2013).
} 
accepted in $1866 .{ }^{3}$ Total reform of the criminal code was completed in 1889 by enactment of a new criminal law.

All the Nordic codes of the 1800 s were strongly influenced by German criminal law theory, representing the state of the art in legal thinking at that time. German influence in legal theory and legislative drafting was mostly mediated through Nordic scholars who had studied at German universities or otherwise studied German philosophy and German scholarship. The idealist philosophy of Hegel, an important source of inspiration for nationalistic movements in many parts of Europe, was highly influential in German criminal law scholarship. At the same time, the codes borrowed from each other.

Intra-Nordic influences were evident throughout the drafting process in all the Nordic countries. This was the case with Denmark following Norway in 1866. Finnish reform, while the last European criminal code based on the German classical school of criminal law, was also influenced by intensive co-operation with leading Swedish legal scholars. Indeed, Nordic legal cooperation started to gain more systematic institutional forms in the coming century.

\subsection{Nordic Co-operation}

As noted in the introductory chapter, Nordic lawyers started convening in 1872. Furthermore, Nordic scholars were active participants in the International Union of Penal Law (I.U.P.L./U.I.D.P.) established in 1889. The first national criminalist association was established in Denmark in the 1890s, and the other Nordic countries followed; their first meeting was held in 1937. Among other activities, these associations have co-published the Scandinavian Journal of Criminal Law and Criminology (Nordisk Tidsskrift for Kriminalvidenskab) for over 90 years. The journal has been an important forum for publishing articles on criminal law research and criminology. Nordic lawyers' meetings increased communication between key legal actors. Very likely this also helped transfer ideas. Nordic neighbours also often took into account one another's already-tested solutions, and it became a common practice to refer to the experience of neighbouring countries when drafting new bills.

\footnotetext{
${ }^{3}$ See Blomstedt Y (1964), Lahti R (1977), p 122-127, Lappi-Seppälä T (1982), p 126 ff.
} 
In 1962, the Scandinavian research Council for Criminology (Nordisk Samarbetsråd för Kriminologi) was established by ministries of justice to "further criminological research within the member countries and advise the Scandinavian governments and the Council on issues related to criminology." In the same year the Nordic governments signed the HelsinkiTreaty, according to article 5 of which "state parties should strive towards the harmonization of the norms related to criminal offenses and punishments". This also became the task of the Nordic Committee for Criminal Law (Nordiska Straffrättskommittén), established by four Nordic Ministers of Justice in 1960. The Committee continued working until 1992, but its main results were produced in the 1960s and 1970s.

The output of the Committee includes establishment of the Nordic extradition system, which can be seen as a forerunner of the European Arrest Warrant. ${ }^{4}$ However, national legislators were not always willing to follow: The Committee was still more like an expert group - not an official committee, and jointly drafted reports were not always politically weighty enough to convince governments and legislative bodies of the benefits of a Nordic solution. One of the topics for which this model of common preparation was tried concerned the rules and principles of exercise of criminal jurisdiction. Finland and Sweden followed commonly drafted instructions whereas Denmark did not, while Norway followed only halfway.

That said, the Committee provided an important platform for establishing joint Nordic policy lines in issues under discussion and national planning tables (see for example the Committee's reports on conditional release and sentencing). This co-operation and exchange of information and experience continued in the form of joint research seminars and annual meetings of criminologists, lawyers and practitioners arranged by the Nordic Criminalist Associations and the Scandinavian Criminological Research Council.

In general, the uninterrupted series of joint Nordic meetings since 1872 has provided a specific environment for legal development in countries that share long common roots but have also experienced different times and different fates in the course of history. Notwithstanding numerous differences in details and legislative solutions, we may with full justification

${ }^{4}$ Council Framework Decision 2002/584 on the European Arrest Warrant and the Surrender Procedures between Member States. Elholm T, Feldtmann B (2014). 
speak of the "Nordic Model of Criminal Justice". This has its foundations in common history and traditions, subsequently in the formation of a specific form of society - the Nordic welfare state - in the latter half of the $20^{\text {th }}$ century, as well as in active co-operation in legal and policy issues during the post WW2 decades. This model - sometimes termed "Scandinavian exceptionalism" - is most notably exemplified in more humane, rational and tolerant sanctioning practices. These practices have received wide international attention among researchers, policy-makers and the media.

\subsection{Nordic Criminal Law Distancing Itself from the German Inheritance}

Whereas throughout the 1800s and still in the early 1900s the Nordic countries were heavily influenced by changing German legal ideologies (first the classical school and subsequently the "sociological" school), this started to change after WW2. The emergence of criminology and empirical social sciences from the 1960s onwards, fresh and critical notions from legal realists and analytical jurisprudence made German-style conceptual jurisprudence look obsolete and out-dated. Reformers, such as Inkeri Anttila in Finland, saw that the entire criminal justice system needed to be rethought. ${ }^{5}$ Johannes Andenaes in Norway conducted ground-breaking research in the field of crime control and deterrence that changed the way the mechanisms of general prevention came to be understood ${ }^{6}$, while Alf Ross in Denmark "deconstructed" practically all key concepts developed by the German scholars of the 1800s. ${ }^{7}$

About the same time, a future leading scholar in Sweden, Nils Jareborg, published a monograph on the two fundamental concepts of German legal theory, act and intent (Handling och Uppsåt), noting that he would not discuss German theory, "since it stands in this field so uninteresting with all of its self-sufficient and unrealistic concept formation. ${ }^{8}$ Subsequently Nordic critical criminologists such as Nils Christie ${ }^{9}$ and Thomas Mathiesen ${ }^{10}$ gained attention far beyond Europe.

\footnotetext{
${ }^{5}$ On Inkeri Anttila's works in English, see Anttila I (2001).

${ }^{6}$ Andenaes J (1974).

${ }^{7}$ Ross A (1975).

${ }^{8}$ Jareborg N (1969), p 6-7, for further works by Nils Jareborg, see Jareborg N (1988) and Jareborg N (2002).

${ }^{9}$ Christie N (1982), Christie N (2000).

${ }^{10}$ Mathiesen T (1990).
} 
The days when Nordic scholars copied German textbooks are clearly over. The scholarly field had become open and it has become acceptable to search for inspiration pragmatically from a variety of foreign sources. This has also become visible in legislative drafting. To take just one example, in the reform of the general part of the Penal Code in Finland, German scholarship was only regarded as one source of inspiration, but it was not in any way given priority as a model. The act deliberately tried to avoid theoretical commitments. Where this was unavoidable, choices were made on the basis of both pragmatic considerations and national and Nordic traditions. Thus, for example, the definition of criminal intent followed (instead of German models) the probability model which had been developed in the other Nordic countries. ${ }^{11}$ Put bluntly, we might conclude that finally the Nordic scholars and the Nordic legislatures saw that they were standing on their own two feet.

\subsection{European Legal Integration and the Nordic Model}

However, the survival of clever national solutions is no longer self-evident. By the 1990s the European political landscape had changed, and since then new forms of international collaboration and influence have been emerging. In the legal field, Nordic harmonization has been supplemented, partly even replaced, by European harmonization. Besides the European Union (EU), the Council of Europe has also been active in drafting conventions on substantive criminal law as well as collaboration in cross-border cases. The European Convention on Human Rights (ECHR) as applied by the European Court of Human Rights (ECtHR) has shaped European criminal procedural systems and to some extent even European systems of criminal law.

The impact of European integration is mostly visible in the field of criminalization. European harmonization has mainly addressed issues of terrorism and organized crime and some other forms of criminality of a cross-border character. As regards systems of sanctions, European harmonization has affected the setting of penalty scales for selected specific crimes. Neither the European Union nor the Council of Europe has seriously tried to address doctrines of penal liability.

Even though a certain tendency of fragmentation is evident in national criminal laws, meaning that international law and international criminal law

${ }^{11}$ See e.g. several of the articles in Lahti R, Nuotio K (1992)-. 
affect certain parts of criminal law whereas the law of the European Union or the Council of Europe affect other parts of criminal law, it still today falls on national legislatures, national courts and (national) scholars to build a totality of all this which is maximally coherent. In plain words, even in these new surroundings the Nordic countries maintain the possibility to defend and further develop the Nordic Model should they find the political will to do so.

\section{Prison Reform and Penal Theories}

\subsection{Introducing Imprisonment in the 1800s}

Preparations to introduce imprisonment as the central sanction started in the Nordic countries in the early 1800s. ${ }^{12}$ However, the formal introduction of imprisonment as the principal sanction in Nordic law occurred first in connection with overall reforms of criminal codes, starting with Norway in 1842, followed by Sweden in 1864, Denmark in 1866 and ending with Finland in 1889. All codes defined imprisonment as the principal sanction and abolished corporal punishment (but maintained the death penalty as an option reserved for the most serious offences, mainly for murder).

Principles of enforcement were, as a rule, confirmed in separate lower-level regulations.

Early prison reform was characterized by struggles between competing enforcement philosophies: the Philadelphian system, developed in the early 1800s under the spiritual influence of the Quakers; and the Auburn system, developed in New York in the 1820s. The Auburn system assumed that the way to reform was through work in total silence, whereas the Philadelphian system was based on the belief that religious meditation in single-cell solitude paves the way to reform and salvation. Neither of these methods proved especially successful, and alternative solutions were produced during the latter half of the century, among them the progressive system developed by Irish prison reformist Walter Crofton. The latter may also be classified as a combination of the Philadelphian and the Auburn systems.

The choice between enforcement philosophies was of fundamental practical relevance as it also determined the way new prisons should be built: either as single-cell prisons suitable for continuous isolation or as facilities with

${ }^{12}$ Chapters-Section 2 and 3 are largely based on Lappi-Seppälä T (2017). 
space for organized work for all inmates. The Nordic countries followed partly different solutions. Prison construction in Sweden around the mid1800s followed the Philadelphian cell model. Norwegian enforcement principles were formulated in co-ordination with Swedish reform following the cell system. The Danish plan in 1842 came up with a compromise: short-term sentences were to follow the isolation model, while longer sentences were to be enforced following the Auburn model.

Finnish prison construction started somewhat later due to general statepolitical reasons. Largely thanks to this delay, the sharpest ideological controversies over enforcement were softened by compromises. Finland never adopted a full-scale Philadelphian single-cell model, but followed a compromise formulated under the 'progressive system' label. This may have been partly a matter of resources: single-cell prisons were far more expensive. However, by the end of the $19^{\text {th }}$ century, doubts about the beneficial effects of long-term total isolation had also started to emerge. The 1889 legislation stressed the aim of rehabilitation, but with religious overtones ("Each prisoner must be provided with spiritual counsel, teaching and advice on how to improve his person and life") as well as work and discipline ("Prisoners must be ordered into hard work, obedience, order and cleanliness", according to the Finnish Act on Sentence Enforcement 1889).

\subsection{Towards Individualized Treatment and Cure}

Plans to redraft the $19^{\text {th }}$ century criminal codes emerged soon after their enactment. In 1902, Norway received a much-appreciated new code, inspired by new ideas from the German sociological school. Denmark enacted a new criminal code, largely based on the same foundations, in 1930. Total reform in Sweden and Finland was postponed, but the principles of enforcement were shaped through partial reform.

Sanction structures in general were revised under the influence of individual preventive programmes of late 20th century criminalist movements. Concrete changes included the introduction and expansion of early release programmes and suspended or conditional sentences, but also the adoption of security measures and specific sanctions for mentally disordered offenders. All the Nordic countries adopted indeterminate confinement of high-risk offenders around the late 1920s. Sweden, Denmark and Norway also established specific institutions for mentally disordered offenders, whereas in Finland the parliament abolished the establishment of a specific 
"psychopath-institution" for resource reasons, though accepting adoption of indeterminate detention for high-risk violent offenders.

The period from 1930 to 1950 may be defined as the golden years of penal rehabilitation. This applies especially to Sweden. Prison law reform started in the mid-1930s, spurred on by Minister of Justice Karl Schlyter's speech in 1934 (which coined the slogan "Empty the prisons"). ${ }^{13}$ During the same year a committee started to work with new enforcement legislation. The enforcement decree of 1938 laid the foundations for upcoming total reform that took place in 1945. This act represents the culmination of treatment ideology in Sweden and forms "the foundation of modern prison services in Sweden." 14 The law abolished the cell system and introduced differentiated enforcement and individualised treatment for different offender groups.

Sweden's prison law confirms four central principles, to be later formulated in the coming reforms: the requirements of human dignity, legality, rehabilitation and harm-minimization. These principles travelled quickly to other Nordic enforcement codes: Denmark in 1946, Finland in 1950 and Norway in 1958. Whether, and to what extent, these ideals and reality are actually met in everyday prison practice is another question. ${ }^{15}$ As regards Finland, the steep post-war crime wave, lack of material resources and the (then) prevailing conservative and punitive criminal policy ideology among leading law professors prevented further adoption of the Swedish model, despite some isolated attempts towards that direction. Changes in this respect had to wait for some fifteen to twenty years more.

\subsection{The Decline of the Rehabilitative Ideal}

Treatment ideology prevailed in the Nordic Countries from the 1930s/40s until the late 1960s. The position of this ideology was strongest in Sweden and Denmark, and weakest in Finland, which was recovering from the hardships of the first half of the $20^{\text {th }}$ century. In the 1960s things started to change. The Nordic countries experienced heated debate on the results of and justifications for involuntary treatment in institutions, both penal and otherwise.

The extensive use of confinement and compulsory treatment in various institutions (such as in healthcare and in the treatment of alcoholics) was

\footnotetext{
13 “Avfolka fängelserna”, see Petersson-Hjelm A (2011), p 148 ff.

${ }^{14}$ Petersson-Hjelm A (2011), p 130 and $177 \mathrm{ff}$.

${ }^{15}$ For critical remarks on this point, see Petersson-Hjelm A (2011) p $262 \mathrm{ff}$.
} 
criticized for being both inhumane and ineffective. Critical research findings on the effects of treatment changed criminal policy priorities from custodial sanctions to community alternatives and to open care measures. Justification for imprisonment shifted from individual prevention and treatment towards general prevention.

The 1960s/70s witnessed radical reforms in the field of social policy, alcohol policy, healthcare, child welfare and criminal policy - of which prison reform was but one aspect. The Nordic countries entered the 1960s from different starting points, and each country had problems of their own. Finland was only now joining the Nordic welfare state family, with much still to catch up on. However, prisoners' rights and prison conditions became a target of political action in all of these countries. Each of them also witnessed the establishment of prisoners' associations in 1966-1968 to improve prisoners' rights and to promote the humanization of prison conditions. ${ }^{16}$

The results of these efforts were realized in a series of reforms around the turn of the 1960s/70s. Major Finnish reforms were conducted in 1971-1975. Swedish prison reform was conducted in 1974. Corresponding Danish reforms were carried out through administrative regulations by a progressive prison director in 1970-1973. In Norway legislative activities were restricted mainly to changes related to indeterminate sanctions.

The decline of treatment ideology did not entail a general shift towards harsher penal regimes and prison warehousing. The core message was to scale down the use of imprisonment and to abolish indeterminate sanctions. The prison reforms that followed at the turn of the 1960s/70s improved the rights of inmates, abolished humiliating disciplinary punishments, introduced prison leave and expanded the system of open facilities.

The resulting criminal policy ideology - "humane neo-classicism" stressed both legal safeguards against coercive care and less repressive measures in general. In sentencing, the principles of proportionality and predictability became the central values. In sentence enforcement, the principles of normality/normalization and minimization of harm replaced the old progressive principle. In prison construction, strategic decisions

${ }^{16}$ KRUM in Sweden 1966, KRIM in Denmark and in Finland 1967 and KROM in Norway 1968, for history and the work these organizations, see Mathiesen T (1974). 
were made towards replacing old, larger, closed prisons with smaller opentype facilities. A major change with strong symbolic significance was the abolition of indeterminate sanctions, including preventive detention, during the early years of the 1970s.

For Denmark, Norway and Sweden the period from the 1960s onwards represents a period of fairly stable and low incarceration rates. For Finland this was the beginning of a long-term reduction in imprisonment rates that continued up to the early 1990s, to the point where Finland reached the general Nordic level of around 60 prisoners for every 100000 inhabitants. ${ }^{17}$

\subsection{Prison Reform 2000 and Human Rights}

The principles laid down in the 1970s outlined penal reforms for the following fifteen to twenty years. The fourth round of prison law reform took place under a complex mixture of increasing punitive demands, growing rehabilitative aspirations and emerging human rights influences.

The 1990s witnessed growth of politicization in criminal policy even in the Nordic countries. ${ }^{18}$ A growing drug problem led to intensification of control and supervision in prison settings. Penal rehabilitation was also experiencing a new return in the form of What Works-thinking. At the same time the growing international human rights movement, the incorporation of the ECHR and the establishment of the ECtHR and the European Committee for the Prevention of Torture and Inhuman or Degrading Treatment or Punishment (CPT) started to influence penal reforms. This influence was visible, not only in national prison laws but partly also on the level of constitutional and fundamental rights. All the Nordic countries revised their prison codes in the 2000s. Denmark ${ }^{19}$ and Norway ${ }^{20}$ were the first countries to do so in 2000, Finland ${ }^{21}$ followed in 2006 and Sweden ${ }^{22}$ in 2010. Iceland ${ }^{23}$, too, enacted a new enforcement code in 2005. The code,

\footnotetext{
${ }^{17}$ These changes and their background have been discussed in more detail in LappiSeppälä T (2007) and (2009).

${ }^{18}$ See for discussions Ugelvik T et al. (2013).

${ }^{19}$ Lov om fuldbyrdelse af straf mv. 1999 no 145. Lov om fuldbyrdelse af straf mv. 1999 no 145.

${ }^{20}$ Lov om gjennomforing av straff $m v .2001$ no 21 . Lov om straff 2005 no 28.

${ }^{21}$ Vankeuslaki / Fängelselag 767/2005

${ }^{22}$ Fängelselag 2010:610:

${ }^{23}$ Lög um fullnustu refsinga No 49/2005. See also Iceland's The Penal Code, Almenn hegningarlög 19/1940.;
}

\begin{tabular}{|l|}
\hline Muotoiltu: Fontti: Kursivoitu, tanska, Korosta \\
\hline Muotoiltu: tanska, Korosta \\
\hline Muotoiltu: Fontti: Kursivoitu, ruotsi (Ruotsi), Korosta \\
\hline Muotoiltu: ruotsi (Ruotsi), Korosta \\
\hline Muotoiltu: Korosta \\
\hline Muotoiltu: Ei Korosta \\
\hline Muotoiltu: Fontti: Kursivoitu, Korosta \\
\hline
\end{tabular}


however, lacks specific provisions related to the general aims of enforcement.

Preparations for a new prison law started in Denmark in 1985. The final bill prepared by the Ministry of Justice was sent to the parliament in 1999 and entered into force in 2000. Prior to the 2000 reform, Danish enforcement legislation was based on administrative regulations alone. The new Corrections Act covers both custodial and community sanctions, as well as enforcement of fines. Perhaps the most important single human rightsoriented change brought about by the 2000 law reform was the introduction of court appeals to replace internal administrative control.

The 2000 Danish prison reform was first and foremost a rule-of-law reform, with the intention of specifically regulating prisoners' rights. The same ideology can be found behind changes that have given the courts a much more active role in the realm of corrections. ${ }^{24}$ Instead of substantial changes in enforcement aims and principles, the ideology behind the 2000 act was to "give Parliament the responsibility for the regulation of this in every way important part of the administration of the state." ${ }^{25}$

Norway received a new Prison Law in 2000 to replace its old treatmentoriented code of $1958 .{ }^{26}$ Preparations for the law started in 1980 and the first proposal was published in 1988 (NOU 1988:37). The Preparatory Committee discussed the principles of enforcement under the framework of classical theories of punishment. Preparation of the final bill took over ten years and the time-span is also visible in the argumentation. While the 1988 proposal included no references to human rights documents, the bill of 2000-2001 devotes specific chapters to this topic with the general notion that "increased focus on individuals' human rights has led the government to propose changes to the existing prison law." 27 Thus the Norwegian Prison Law 3:38 allows the use of coercive measures "only if the circumstances make this strictly necessary, and less forceful measures have been attempted in vain or will obviously be inadequate". With reference to the decisions of the Human Rights Commission from the late 1980s, the bill also stressed the need to restrict the use of solitary confinement only to cases where it is

${ }^{24}$ Greve V, Snare A (2009), p 311.

${ }^{25}$ Greve V (2014), p 222.

26 Lov om gjennomføring av straff $m v .2001$ no 21. onko aikaisemmin?

${ }^{27}$ See Det Kongelige Justis- og Politidepartement (2000), p 12-18 
deemed to be absolutely necessary as a preventive measure, never as punishment. ${ }^{28}$

Sweden reformed its prison law in 2010 on the basis of an extensive committee report published in 2005 (SOU 2005:54). The committee work was inspired by emerging ideas on new rehabilitation (What Works). The proposal laid strong emphasis on the old progression principle and increased individualisation with progress plans, and even re-introduction of the system of privileges attainable through good behaviour. New elements, compared to the previous code from 1974, included increased emphasis on reducing the risk of reoffending and on security. Presumably the most important single change motivated by international obligations and human rights requirements was replacement of the internal administrative appeals mechanism with a court-based system. Compared to the Danish and Norwegian codes, the aims of enforcement and leading principles are also defined in more detail consisting of the general aim of rehabilitation, the aim of harm minimization, respect for human dignity, and the like.

In Finland, preparations for a new prison law started with the appointment of a prison law committee in 1998. The new prison law entered into force in 2006. The reform was much influenced by ratification of the ECHR in 1989 and constitutional reforms carried out in 1995 and 2000. Joining the Council of Europe and ratification of the ECHR at the time of constitutional reform opened the window of opportunity for incorporating human rights as part of fundamental rights in the constitution. This proved to play an important role in revisions of prison law. The constitution imposed stricter demands than before on legal regulation in all decisions dealing with deprivation of liberty. It also obliged the legislator to define the rights and obligations of prisoners in greater detail than before. Additional pressures towards total revision of the prison law emerged from the fact that the old enforcement act had become fragmented and outdated from a penological point of view.

Preparatory work for the code also used the support provided by recommendations from the CPT, for example on issues related to introduction of a structured enforcement plan, the need for a comprehensive strategy regarding separation of prisoners for safety and security, and

\footnotetext{
${ }^{28}$ Despite these notions, the introductory chapter of the bill stresses preventive aims and security.
} 
prisoners' right to appeal. All in all, the 2006 reform of prison law can be characterized first and foremost as a rule-of-law reform. As stated in the governmental bill, the act "aims to bring the prison law in accordance with the requirements of the new constitution, to define the obligations of prison authorities in more detail, to increase legal safeguards and transparency in prison administration, to reorganize the imprisonment process to a more structured and planned process and increase investments in rehabilitative program- and treatment work and thereby also to reduce recidivism." (Gov Prop 262/2004).

\section{Principles of Enforcement}

\subsection{Rights-oriented Principles}

All codes include declarations of leading principles of enforcement. Some of them can be conceived as penological aims, some as expressions of broader values related to human and fundamental rights to be taken into account in pursuing those aims. Some can also be understood as regulatory principles that define the mode of enforcement in specific areas. ${ }^{29}$ The following section gives a brief overview of some of these principles, using Finnish prison law - being the most detailed in this respect - as a point of reference.

The principle of inviolability of human dignity is confirmed in section 1 subsection 2 of the Finnish Constitution ${ }^{30}$ : "The Constitution shall guarantee the inviolability of human dignity." It sets human dignity as the basic value behind the other fundamental rights provisions. Subsection 7.2 states that "no one shall be sentenced to death, tortured or otherwise treated in a manner violating human dignity." Section 22 of the constitution, in turn, states that "public authorities shall guarantee the observance of basic rights and liberties and human rights." These requirements have been incorporated in Nordic prison laws since the mid-1940s. They are also repeated in the present codes: The Penal Code of Finland ${ }^{31}$ (FPCE) "Prisoners shall be treated fairly and with respect for their human dignity" (FPC $\leftarrow$ 1:5.1), The

\footnotetext{
${ }^{29}$ Principles alone, of course, are not enough. Their contents need to be specified. This is addressed by separate provisions dealing with issues such as arrival and placement in prison, basic care and accommodation, participation in activities, contacts with the outside world, prison order and discipline and inspections.

${ }^{30}$ Suomen perustuslaki / Finlands grundlag 731/1999.

${ }^{31}$ Rikoslaki / Strafflag 39/1889.
}

Muotoiltu: Ei Korosta
Muotoiltu: Ei Korosta
Muotoiltu: Ei Korosta


Swedish Penal Code ${ }^{32}$ (SPCC) "Every prisoner shall be treated with respect for his or her human dignity and with understanding for the special difficulties associated with the deprivation of liberty" (SPCE $\underline{1: 4)} .^{33}$

Another principle that should be mentioned is the principle of legality and imprisonment as loss of liberty only. -Offenders are sent to prison as punishment, not for punishment. ${ }^{34}$ The message behind this famous phrase has been given different formulations. One formulation can be found in Finnish law: "The content of imprisonment shall be loss or restriction of liberty" (FPCL 1:3.1). European Prison Rules (2006) ${ }_{-}^{35} 102.2$ states:

"Imprisonment is by the deprivation of liberty a punishment in itself and therefore the regime shall not aggravate the suffering inherent in imprisonment." The Danish formulation of 1945 states that "the punishment of imprisonment solely consists in the deprivation of liberty, and that the prisoner otherwise retains the rights and duties of a citizen in society". ${ }^{36}$ These formulations embody at least two distinct but interconnected claims: one related to prisoners' position as subjects of rights and another related to the content of imprisonment.

The first claim states that prisoners are no longer "slaves of the state", but that their rights are protected by law like any other citizen. This requirement is constitutionally confirmed in the Finnish Constitution (section 7.3): "The rights of individuals deprived of their liberty shall be guaranteed by an Act of Parliament." The section rejects the prior "assumption of institutional powers" (or "inherent limitations"). ${ }^{37}$ Since the rights of persons who have been deprived of their liberty must be safeguarded by an Act of Parliament, all restrictions on these rights must in Finland be based on a parliamentary act, not regulations of lower level statutes or correctional orders issued by the administration according to explicit or implicit broad authorization from

\footnotetext{
${ }^{32}$ Brottsbalk 1962:700.

${ }^{33}$ This requirement is listed as the $1^{\text {st }}$ rule both in the European Prison Rules EPL 2006 and the The United Nations Standard Minimum Rules for the Treatment of Prisoners (the Nelson Mandela Rules), UN Mandela rules 2015.

${ }^{34}$ Quoted by Ruck 1951.

${ }^{35}$ Recommendation Rec(2006)2 of the Committee of Ministers to member states on the European Prison Rules.

${ }^{36}$ See Greve V, Snare A (2009), p 310-311.

${ }^{37}$ See-van Zyl Smit D, Snacken S (2009).
}

Muotoiltu: Korosta

Muotoiltu: Ei Korosta

Muotoiltu: Ei Korosta 
the parliament. ${ }^{38}$ The second claim is about the content of imprisonment. It is no longer required or allowed to impose extra hardship on prisoners for reasons related to the "aims of punishment" (whether retribution or deterrence). Loss of liberty, as such, is enough.

The principle of minimum intervention is linked with the second claim above. Thus, the cited Finnish provision continues, "The enforcement of imprisonment may not restrict the rights or circumstances of a prisoner in any other manner than that provided in the law or necessary due to the punishment itself" (FPCL L 1:3.1). Swedish law states that "enforcement may not entail limitations of the prisoner's liberty other than those that follow from this Act or are necessary to maintain good order or security" (SPCE 1:6.1). According to The Danish Penal Code ${ }^{39}$ (DPCE), "during sanction enforcement an individual must not have restrictions imposed on his existence other than those provided by law or which result from the sanction itself” (DPC $\underline{L} 4$ §). Restrictions need to be based on clear authorization by law.

The normality principle occupied the central position as the leading principle of enforcement in Finland in the 1970s. As formulated in the present law: "The conditions in a prison shall be arranged, to the extent possible, so that they correspond to the living conditions prevailing in society." (FPE $E$ 1:3) The other Nordic countries lack explicit formulations of the principle, but it forms a clear starting point for the regulation of prison life and conditions in general. ${ }^{40}$ In simple terms, the principle calls for the abolition of certain practices followed in prison life only (for example, the requirement to wear prison clothes). In broader terms, the principle affects the ways in which work, education, and training are arranged in prisons. ${ }^{41}$

\footnotetext{
${ }^{38}$ As noted by critics, vague criteria (such as "the demands of security") easily water down the intended legal safeguards. For a criticism of Danish law, see Greve V, Snare A (2009).

${ }^{40}$ As noted by Engbo HJ (2017), the normality principle does not have fixed content. He makes a distinction between proactive and defensive approaches. The proactive approach obliges the authorities to arrange conditions enabling prisoners to live as normally as possible inside prison. The defensive approach entails a duty of non-interference in the form of minimum intervention.

${ }^{41}$ For a detailed description of application of the normality principle in Finland, see Hartoneva A (2002) and for Denmark Engbo HJ (2005), p 44-45 and Engbo HJ (2017).
} 


\subsection{Aim-oriented Principles}

The rehabilitation principle belongs among so-called aim-oriented principles. Rehabilitation remains the central aim in enforcement, even if the actual use of imprisonment is based on other motives. ${ }^{42}$ All the Nordic codes stress rehabilitative-related aims, but with different wordings. The Finnish Prison Law states: "The goal of the enforcement of imprisonment is to increase the ability of a prisoner to lead a crime-free life by promoting the prisoner's potential to cope and his adjustment to society as well as to prevent the committing of offences during the term of sentence." (FPC $\underline{E}$ 1:2) The section covers both more narrowly focused efforts for social rehabilitation and reduction of recidivism, as well as broader attempts to provide social support and networks promoting social adjustment and social survival.

The Danish Corrections Act $\underline{43}(3 \S)$ states that "The enforcement of the sanction shall take place with necessary regard both for the execution of the sanction and for the need to assist or influence the convicted person to lead a law-abiding life". Similar elements are to be found in Swedish law: "Enforcement shall be devised so as to facilitate the prisoner's adjustment in the community and counteract the negative consequences of deprivation of liberty." (SPCE $\underline{t}$ 1:5.1) However, the law also puts more emphasis on efforts to prevent re-offending: "Enforcement shall, so far as possible and without neglecting the requirement to protect the community, focus especially on measures intended to prevent re-offending. “ $(\mathrm{SPC} E$ 1:5.2)

The wording of The Norwegian Penal Code ${ }^{44}$ (NPCE) is more ambiguous: "A sentence shall be executed in a manner that takes into account the purpose of the sentence, which serves to prevent the commission of new criminal acts, reassures society, and within this framework ensures satisfactory conditions for the prisoners." (NPC L 1:2). Furthermore, "sanctions shall be executed in a manner that satisfies the need for security. The substance thereof shall be based on the measures available to the Correctional Services for assisting a convicted person to adjust to society. The Correctional Services shall make suitable arrangements for enabling a convicted person through efforts of his or her own to avoid committing new

${ }^{42}$ See the Lag, (1974:203) om kriminalvaird i anstalt Swedish KvaL.se 4 §: Enforcement of imprisonment shall be carried out so that the prisoner's adaptation to society is furthered and the detrimental effects of the deprivation of liberty are counteracted. 43 Straffuldbyrdelsesloven, 2017 no 1491.

Muotoiltu: Ei Korosta
Muotoiltu: Ei Korosta
Muotoiltu: Ei Korosta
Muotoiltu: Ei Korosta

Muotoiltu: Fontti: Kursivoitu, Korosta

Muotoiltu: Korosta

Muotoiltu: Fontti: Kursivoitu, Korosta

Muotoiltu: Korosta

Muotoiltu: Fontti: Kursivoitu, tanska, Korosta

Muotoiltu: tanska, Korosta

Muotoiltu: tanska 
criminal acts." (NPCL $1: 3.1.)^{45}$ In addition, it does not mention adjustment to society but only prevention of crime.

The aim of minimizing harm can be seen as another re-formulation of minimum intervention (and the normality principle), but with a clearer and more concrete aim. The Finnish code links the avoidance of harmful effects of prison life and maintaining health and social functionality in the same paragraph: "The ability of a prisoner to maintain his health and functional ability shall be supported. The goal is to prevent any detriment resulting from the loss of liberty." (FP드 1:3) The Swedish code combined the aim of harm minimization with the general aim of social rehabilitation (see above SPCE 5:1). The Norwegian code discusses this principle in connection with remand prisoners: "In the case of persons remanded in custody the Correctional Services shall make suitable arrangements for remedying the detrimental effects of isolation." (NPCE $t$ 1:2.2). Efforts to maintain health include equal healthcare services for prisoners (as compared to the rest of the population). Harm may be minimized by providing psychosocial support and treatment and by supporting prisoners' contacts with the outside world.

\subsection{Juveniles}

The Nordic countries abolished specific juvenile prisons in the 1970s as a reaction against indeterminate sanctions. Since then custodial care orders have mostly been implemented under the child welfare system.

Consequently the number of young offenders in actual prisons has remained "too small" to justify establishing specific institutions for juveniles only.

This has sometimes aroused critical observations from the CPT.

The response to this criticism is that juveniles are kept separate, provided that this is in their best interest: "When enforcing the imprisonment of juveniles, who have committed their offences when under 21 years of age, special attention shall be paid to the needs arising from the age and stage of development of the prisoner" (FPCE 1:5.2). And furthermore: "A prisoner under 18 years of age shall be kept separate from adult prisoners unless otherwise required by his best interests" (FPCE 4:8). Similarly the Swedish code states "A prisoner who is under the age of 18 years may not be placed so that he or she is together with prisoners aged 18 or over unless this can be considered to be in his or her best interests" (SPCL $t$ 2:3), as does the

\footnotetext{
${ }^{45}$ See further Greve V, Snare A (2009), p 316.
} 
Norwegian code: "Particular importance shall be attached to a child's right of access to his or her parents during the execution of a sanction." (NPCE$t$ $1: 3.2)$

\section{Nordic Model - Past, Present and Future}

\subsection{Common Route with Different Paths}

When adopted and presented as a replacement for corporal punishment in the early 1800 s, prisons were supposed to be frightening places with enough deterrent potential. Nordic prisons were no exception. ${ }^{46}$ The principles of enforcement in $19^{\text {th }}$ century prisons were a combination of deterrence, retribution and reform. Rehabilitation, however, was to be achieved, not by treatment and support in our understanding of the words, but either by solitude and discussion with one's conscience, or through hard work and religious teaching. Criminal codes themselves were influenced by the classical German theory of criminal policy with its emphasis on retribution and general prevention. In the $20^{\text {th }}$ century, religious-oriented enforcement practices, the atonement of sins in solitude, and reform through hard labour were displaced by scientifically informed views about the causes of crime and the effects of punishment, with stress on more individualized and differentiated treatment. Adults and juveniles were kept separately in separate institutions, as were chronic recidivists and offenders suffering from mental disorders.

The process culminated in the golden years of penal rehabilitation in Sweden from the 1930s to the 1950s. This reform was essentially a socialdemocratic welfare project reflecting both changed conceptions of the tasks and responsibilities of the state and the enhanced social and material conditions of the (Swedish) "peoples' home" providing shelter and support for the weak and those in need. ${ }^{47}$ Other Nordic countries followed, some more closely (Denmark and Norway), and some from a distance (Finland).

From the 1960s/70s onwards, social-liberal critics of criminal law raised barriers against treatment without consent, use of indeterminate sanctions and overuse of incarceration in general. While these reforms were conducted largely under the same flag in all the Nordic countries, their

\footnotetext{
${ }^{46}$ For critical reports on conditions in $18^{\text {th }}$ and $19^{\text {th }}$ century Nordic prisons, see Scharff Smith P, Ugelvik T (2017), p 10-12.

${ }^{47}$ Petersson-Hjelm A (2011), p 361.
} 
starting points were different. For Finland the main target was reduction of the high number of prisoners, in international terms, by use of shorter sentences and alternatives to imprisonment. Other Nordic countries mainly distanced themselves from the overly optimistic ideal of penal rehabilitation, while still maintaining rehabilitative-oriented practices as part of their sanction structures.

In the North the idea of rehabilitation did not fade away in the 1970s. Rather, claims and conclusions were less radical and more modest: to admit that imprisonment should not be used because of its rehabilitative potential, to abolish all forms of non-consensual treatment, and to restrict the use of penal confinement based on empirically insecure assumptions regarding offenders' future behaviour.

The Nordic criminal justice systems spent the years from the 1970s to the 2000s in a moderate penal climate, by comparison with changes experienced in other western regions and countries during that period. All Nordic countries had their share of the "new punitive turn", albeit in different form, scale and time. Still, the relative magnitude of these changes - in comparative terms - remained modest to the extent that the Nordic countries still maintained the characterization of "Nordic penal exceptionalism" as part of comparative criminal political analyses. ${ }^{48}$

\subsection{Nordic Penal Exceptionalism - Does It Exist, and Will It Last?}

The Nordic welfare state, along with its underlying structures, values and practices, has enabled the creation and defence of a criminal political model that today is characterized by internationally low prison population rates, humane prison conditions and a general commitment to rehabilitating and reintegrating offenders into society. ${ }^{49}$ The outcome can be characterized by a pragmatic and non-moralistic approach and with a clear social policy orientation. It reflects the values of the Nordic welfare-state ideal and emphasizes that measures against social marginalization and equality also operate as measures against crime.

\footnotetext{
${ }^{48}$ Pratt J, Eriksson A (2013).

${ }^{49}$ For comparative analysis along these lines, see Cavadino M, Dignan J (2006) and Lacey N (2008). The internal logic between political economy, welfare and social values and their relevance for penal policy formation has been analyzed in more detail in LappiSeppälä T (2008).
} 
The survival of this model is by no means self-evident. Nor does a consensus exist among Nordic scholars about the "true nature" of "Nordic exceptionalism", or about the survival of the Nordic welfare state itself. Socio-economic and political structures have experienced radical changes, the hegemony of social-democratic parties is already history, as indeed are the days of centralized tripartite wage agreements that once paved the way towards more egalitarian wage policies. Privatization and market forces are stepping into social service sectors, and populist right-wing protest parties wield increasing influence in national politics.

As regards the content of penal policy, intra-Nordic criticism has challenged many of the flattering characterizations of international observers by pointing out examples of increasingly punitive sanction practices, the toughening of prison control to curb the spread of drugs in prisons, excessively punitive pre-trial practices and the use of solitary confinement, not to mention the general hardening of penal rhetoric. Recent demographic changes and large-scale immigration have changed penal debate in some countries (most notably in Norway), while others have been troubled by specific crime problems (such as motor-cycle gangs in Denmark). ${ }^{50}$

So, is it time to say goodbye to Nordic penal exceptionalism (if indeed it ever existed)? Are we perhaps witnessing the "end of Nordic humane and rational penal policy"? Before answering these questions, some hard facts need to be acknowledged: Children under 15 are not punished and the number of children aged 15-17 in penal institutions is counted in tens; prisoners maintain all their constitutional rights, rights that are defined in detail in the law, monitored nationally and internationally, and protected in practice; a substantial number of prisoners are serving their sentences in open facilities; the use of indeterminate confinement is either prohibited or limited to a minimum; criminalizations still follow the principle of ultimaratio and rule-of-law, albeit under growing pressure from the European Union; political and criminological discourse about crime prevention takes place within the framework of social- and situational prevention, with only fragmented notions towards criminal law (usually in connection with highrisk violent recidivists or sexual offences); the sanction system has been reformed towards community measures with stress on social reintegration

\footnotetext{
${ }^{50}$ For critical discussion, see Barker V (2017), Ugelvik T, Dullum J (2012), Scharff Smith P, Ugelvik T (2017), Shammas VL (2017). For long term analysis of legislative changes in Nordic countries, see Lappi-Seppälä T (2016b).
} 
(and not plain control) and with the declared aim of reducing the use of custodial sanctions.

As a result, the Nordic countries have fewer prisoners than any set of industrialized countries in the world. During the last ten years the number of prisoners has also decreased on average by a little over ten per cent (and the number of incoming inmates by almost 30 per cent). ${ }^{51}$

These elements can be acknowledged without falling into complacency or into the false belief that this state of affairs is secure in the future. Nor is there reason to assume that Nordic criminal justice systems are functioning without flaws and injustices. We need to be prepared for the possibility that things may take an adverse turn, and we need to maintain a critical view towards our own practices. Affluent societies, such as the Nordic countries, can and must be able to produce penal practices that correspond to their levels of socio-economic resources, pay full respect to human rights, and give true prominence to the social and humanitarian values underpinning the ideal of the Nordic welfare state.

\section{References}

Andenaes J (1974) Punishment and Deterrence. Michigan, Ann Arbor: University of Michigan Press

Anttila I (1981) Kansainväliset vaikutteet Suomen vankeinhoidon kehityksessä. In E Suominen E (ed) Suomen vankeinhoidon historiaa: Osa 1, Katsauksia vankeinhoidon kehitykseen. Helsinki, Valtion painatuskeskus, p 325-354

Anttila I (2001) Ad Ius Criminale Humanius. Essays in Criminology, Criminal Justice and Criminal Policy. Helsinki, Finnish Lawyers' Association

Asp P, Elholm T, Frände D, Walhberg M (2010) Eurooppalaisen kriminaalipolitiikan manifesti. Lakimies, 4:644-648

Barker V (2017) Nordic vagabonds. The Roma and the logic of benevolent violence in the Swedish welfare state. European Journal of Criminology 14(1):120-139

Betænkning om en lov om fuldbyrdelse af straf mv. Bind I. Arbejdsgruppe nedsat af Straffelovrådet Betænkning nr. 1181/1989

Blomstedt Y (1964) Rikoslakireformin ensimmäiset vaiheet vuoden 1866 osittaisuudistuksiin saakka. Historiallinen Arkisto 59. Turku, Turun sanomalehti ja kirjapaino Oy

51 The fall is steepest in Finland from 3776 to 2859 prisoners (-24 \%), followed by Sweden (from 7196 to 5664, $-21 \%$ ). Norway forms the exception, with sharply increasing numbers of prisoners $(3300->3927,+19 \%$, which has also gained the attention of the Norwegian research community). 
Cavadino M, Dignan J (2006) Penal systems: a comparative approach. London, SAGE Publications

Christie N (1982) Limits to Pain. Oxford, Robertson

Christie N (2000) Crime Control as Industry. London, Routledge

Det Kongelige Justis- og Politidepartement (2000) Ot.prp. nr. 5 (2000-2001).

Ehrström KG (1859) Om principen för fängelsestraffets ordnande. Helsinki, J.C. Frenckell $\&$ Son

Elholm T, Feldtmann B (2014) Nordic trends of jurisdiction - An international perspective. In Elholm T, Feldtmann B (eds) Criminal Jurisdiction: A Nordic Perspective. Copenhagen, DJØF Publishing, p 149-151

Engbo HJ (2005) Straffulbyrdelseret. Copenhagen, Juris- og Okonomiforbundets Forla

Engbo HJ (2017) Normalisation in Nordic Prisons - From a Prison Governor's Perspective. In Scharff Smith P \& Ugelvik T (eds) Scandinavian Penal History, Culture and Prison Practice: Embraced By the Welfare State? London, Palgrave Macmillan, p 327-352

Eriksson T (1967) Kriminalvård. Idée och experiment. Stockholm, P.A. Norstedt \& Söners förlag

Eskeland S (1989) Fangerett. En Studie av rettsikkerhet ved fullbyrdelse av fengselstraff. Oslo, Tano

Forsman Jaakko (1896) Suomen lainsäädännön historia: sen pääpiirteet. [1.] osa, Luentojakso. Helsinki Söderström

Greve V, Snare A (2009) Ideologies and realities in Prison Law: Some trends. In Wahlgren P (ed) Scandinavian Studies in Law vol 54. Stockholm, Stockholm University of Law Faculty, p 305-332

Greve V (2002) Straffene. Copenhagen, Jurist- og Økonomforbundets Forlag

Greve V (2014) The sanctioning system. In Langsted B, Garde P, Greve V, Criminal law in Denmark. Copenhagen, DJÖF publishing, p 100-113

Hartoneva A (2002) Normaalisuusperiaate Suomen vankeinhoidossa. Rikosseuraamusviraston julkaisuja 3/2002. Vammala, Vammalan kirjapaino

Hartoneva A, Mohell U, Pajuoja J (2016) Yhdyskuntaseuraamukset ja vankeus. Helsinki, Tietosanoma

Häthén C (1990) Straffrättsvetenskap och kriminalpolitik. Se europeiska straffteorierna och deras betydelse för svensk strafflagstiftning 1906-1931. Lund, Lund University Press

Jareborg N (1988) Essays in Criminal Law. Uppsala, Iustus förlag

Jareborg N (2002) Scraps of Penal Theory. Uppsala, Iustus förlag

Koskenniemi L, Lappi-Seppälä T (2017) Assessing the Role of International Monitoring Instruments and their Impact on Prison Conditions in the Nordic Countries. In Cliquennois G, \& de Suremain H (eds), Monitoring penal policies in Europe. London, New York, Routledge

Lahti R (1977) Criminal sanctions in Finland: A System in Transition. Scandinavian Studies in Law 21:119-157

Lacey N (2008) Women, crime, and character : from Moll Flanders to Tess of the D'Urbervilles. Oxford, Oxford University Press

Lång KJ (1981) Vankeinhoitolaitosta johtaa oikeusministeriö - Katsaus vankeinhoidon keskushallinnon muodostumiseen. In Suominen E (ed) Suomen vankeinhoidon 
historiaa: Osa 1, Katsauksia vankeinhoidon kehitykseen. Helsinki, Valtion painatuskeskus, p 10-35

Lappi-Seppälä T (1982) Teilipyörästä terapiaan - piirteitä rangaistusjärjestelmän historiasta. Vankeinhoidon historiaprojektin julkaisu 9/1982. Helsinki

Lappi-Seppälä T (2007) Penal Policy in Scandinavia. In Tonry M (ed) Vol. 36 Crime and Justice: A Review of Research. Chicago, The University of Chicago Press

Lappi-Seppälä T (2008) Trust, Welfare, and Political Culture. Explaining National Differences in Penal Severity. In Tonry M (ed), Vol. 37 Crime and Justice: A Review of Research. Chicago, The University of Chicago Press

Lappi-Seppälä T (2009) Imprisonment and Penal Policy in Finland. Scandinavian Studies in Law 54:333-380

Lappi-Seppälä T (2011) Nordic Youth Justice: Juvenile Sanctions in Four Nordic Countries. In Tonry M, Lappi-Seppälä T (eds) Vol. 40 Crime and Justice: A Review of Research. Chicago, University of Chicago Press

Lappi-Seppälä T (2016a) Life Imprisonment and related institutions in the Nordic Countries. In van Zyl Smit D, Appleton C (eds), Life Imprisonment and Human Rights. Oxford and Portland, Oregon, Onati International series in Law and Society, p 461-505

Lappi-Seppälä T (2016b) Nordic Sentencing. In Tonry M (ed) Vol. 45 Crime and Justice: A Review of Research, vol. Chicago, University of Chicago Press

Lappi-Seppälä T (2017) Enforcement Principles and Nordic Prison Reform 1800-2000. Tidskrift Utgiven av Juridiska Föreningen i Finland 2-4:426-449

Letto-Vanamo P, Ylikangas H (1981) Hajapiirteitä laillisen vapaudenriiston ja sen toimeenpanon kehityksestä esiteollisena aikana. In Suominen E (ed) Suomen vankeinhoidon historiaa: Osa 1, Katsauksia vankeinhoidon kehitykseen. Helsinki, Valtion painatuskeskus, p 37-84

Manifesto on European Criminal Policy. http://www.europarl.europa.eu/document/activities/cont/201112/20111207ATT334 75/20111207ATT33475EN.pdf. Accessed 6 June 2018

Mathiesen T (1974) Scandinavian Studies in Criminology, Volume 4: The Politics of Abolition. Essays in Political Action Theory. Scandinavian Studies in Criminology. Oslo, Universitetsforlaget

Mathiesen T (1990) Prison on Trial: A Critical Assessment. London, Sage

Nordskov-udvalget (2000) Placering af indsatte. Indstilling agfgivet af Differentieringsudvalget Kobenhavn: Direktroratet for Kriminalforsorgen. http://krim.dk/undersider/retskilder/institutions-placeringNordskovudvalget[1].pdf. Accessed 6 June 2018

Norvin Nilsson I (2014) Forandringer mod mindre frihedsstraf I Danmark 1967-1977. Institut for Kultur og Identitet Historia. Roskilde Universitet

Nytt Straffsystem 1977. Brottsförebyggande rådet. Rapport.

Olivecrona SRDK (1891) Om dödsstraffet. Uppsala

Paterson A (2015) Paterson on Prisons. The collected papers of Sir Alexander Paterson. London, Frederick Muller

Petersson-Hjelm A (2011) Fängelset som välfärdsbygge. Institutet för rättshistorisk forskning. Rättshistoriskt bibliotek, Band 68, Stockholm 
Pratt J, Eriksson A (2013) Contrasts in Punishment: Contrasts in Punishment. Routledge, London, New York

Ross A, (1975) On Guilt, Responsibility and Punishment. University of California Press, Berkeley

Shammas VL 2017: Prisons of Welfare. Incarceration, Social Democracy, and the Sociology of Punishment.Department of Sociology and Human Geography. Faculty of Social Sciences, University of Oslo

Scharff Smith P, Ugelvik T (2017) Scandinavian Penal History, Culture and Prison Practice. Embraced by the Welfare State. Palgrave MacMillan, London

Straffelovrådets betænkning nr. 1355/1998 om en lov om fuldbyrdelse af straf m.v. Delbetænkning III om sanktionsspørgsmål. http://www.krim.dk/undersider/retskilder/betaenkning1355-straffuldbyrdelse.htm. Accessed 6 June 2018

Suominen E (1981) (ed) Suomen vankeinhoidon historiaa. Osa 1. Katsauksia vankeinhoidon kehitykseen. Helsinki, Valtion painatuskeskus

Ugelvik T, Dullum J (2012) Penal Exceptionalism? Nordic Prison Policy and Practice London. New York, Routledge

Viljanen J (2007) The European Convention of Human Rights and the Transformation of the Finnish Fundamental Rights System: The Model of Interpretative harmonisation and Interaction. Scandinavian Studies of Law vol 52, pp 299-320

von Hofer H (1993) Fängelset. Uppkomst - avskräckning - inkapacitering. Tre kriminologiska studier. Stockholm, Kriminologiska institutionen, Stockholms universitet

Zyl van Smit D, Snacken S (2009) Principles of European Prison law and Policy. Penology and Human Rights. Oxford, Oxford University Press

Tapio Lappi-Seppälä, LLD, Professor-on Criminal Law, Director of the Institute of Criminology and Legal Policy, University of Helsinki

Kimmo Nuotio, LLD, Professor, University of Helsinki 